\title{
DEFICIT IRRIGATION STRATEGIES FOR THE WESTERN U.S.
}

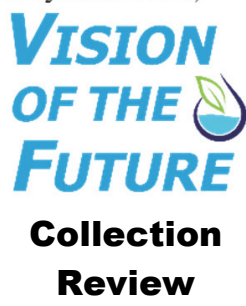

\section{HighLIGHTS}

- Deficit irrigation may maximize net income when irrigation water supplies are limited or expensive.

- Water production functions are used with economic parameters to maximize net income with deficit irrigation.

- Net income may be insensitive to the amount of deficit irrigation if production costs are appropriate for anticipated yield.

- Deficit irrigation increases risk.

\begin{abstract}
Competition for, regulation of, and depletion of water supplies in the western U.S. has resulted in reduced water available for irrigating crops. When the water supply is expensive or inadequate to meet full crop water requirements, deficit irrigation (DI) may maximize net income (NI) by reducing use of expensive water or irrigating more land with limited irrigation supplies. Managed DI entails rational planning and strategic water allocation to maximize NI when water supplies are constrained. Biophysical and economic relationships were used to develop NI models for DI and determine water allocation strategies that maximize NI under three types of water supply constraints. The analyses determined that potential benefits of DI are greatest when water is expensive, irrigation efficiency is low, the water supply is flexible, and rainfed production is not economically viable. When production costs are appropriate for anticipated yields, NI is less sensitive to DI planning decisions. Deficit irrigation will become more important as irrigation water supplies continue to decline in the future. Net income analysis can assist growers in making rational DI decisions.
\end{abstract}

Keywords. Deficit irrigation, Economic analysis, Irrigation management, Net income, Optimization, Water productivity.

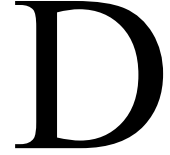
eficit irrigation (DI) is when the irrigation water applied to a crop is less than required to meet full crop water requirements resulting in evapotranspiration (ET) less than the maximum crop ET. For a few crops and conditions, irrigation is intentionally reduced to attain a desired plant response or product characteristic or quality, for example, to reduce vegetative growth, increase fruit quality and value, induce maturity, or facilitate harvest. This is often referred to as regulated DI, or RDI

(c) (1) $\Theta$ The authors have paid for open access for this article. This c. $\mathrm{BY}_{\mathrm{NC}} \mathrm{ND}$ work is licensed under a Creative Commons AttributionNonCommercial-NoDerivatives 4.0 International License https://creative commons.org/licenses/by-nc-nd/4.0/

Submitted for review on 22 May 2020 as manuscript number NRES 14114; approved for publication as a Invited Review Article and as part of the National Irrigation Symposium 2020 Collection by the Natural Resources \& Environmental Systems Community of ASABE on 4 September 2020

Mention of company or trade names is for description only and does not imply endorsement by the USDA. The USDA is an equal opportunity provider and employer.

The authors are Thomas J. Trout, Agricultural Engineer (retired), USDA-ARS Water Management and Systems Research Unit, Fort Collins, Colorado; Terry A. Howell, Agricultural Engineer (retired), USDA-ARS Conservation and Production Research Laboratory, Bushland, Texas; Marshall J. English, Professor Emeritus, Department of Biological and Ecological Engineering, Oregon State University, Corvallis, Oregon; Derrel L. Martin, Irrigation and Water Resources Engineer, Department of Biological Systems Engineering, University of Nebraska, Lincoln, Nebraska. Corresponding author: Thomas Trout, 2150 Centre Ave., Bldg. D, Fort Collins, CO 80526; phone: 970-492-7419; e-mail: thomas.trout@usda.gov.
(Chai et al., 2016). However, in most cases, DI results in reduced yield and gross income. DI may occur due to water delivery or application constraints or errors in scheduling irrigations, or it may be an intentional management practice to maximize net income under conditions of an inadequate or expensive water supply.

In this article, we discuss managed DI in which the manager is aware of water supply limitations and value and has flexibility to adjust the irrigated area and production inputs. Two constrained water supply conditions will be considered:

- The water supply is adequate but expensive or has value for other uses.

- The water supply is limited by volume due to legal limitations on seasonal or multi-seasonal groundwater extraction, groundwater pumping capacity constraints, or an in-season reduction in water supply.

These two conditions are also referred to as land-limited constraints and water-limited constraints (Martin et al., 1989a; English, 1990).

We assume that the goal of the manager is to maximize net income with acceptable risk. The context is western U.S. irrigated agriculture in which precipitation is inadequate to meet full crop water requirements in most years. Precipitation, crop water requirements, irrigation application methods, soils, and crops vary widely across the western U.S. Thus, irrigation requirements and DI management strategies vary depending on the regional environment and the objectives of the manager. For example, DI strategies are influenced by the 
portion of full crop water requirements that is met by precipitation. Rainfed production is a viable alternative to irrigated crop production for some crops in much of the Great Plains in most years, but cropped agriculture without irrigation is not viable in much of the region west of the Rocky Mountains.

When the water supply is adequate and not expensive, the usual goal has been to maximize production by meeting full crop water requirements. Many irrigated areas in the western U.S. experience limited water supplies because productive irrigable cropland exceeds available water supplies. The water supply constraint is increasing due to competition for water and depletion of groundwater. Limited or expensive water may motivate changing the production goal from maximum yields and gross income per unit area to managing for acceptable yields that maximize economic returns within the water supply constraints.

Water supply limitations may be long-term and predictable or short-term and unanticipated. The planning horizon for DI management determines the available options. Awareness of long-term limitations allows the producer to make land and infrastructure investments appropriate to the water supply (English et al., 1990). Irrigation water supply may vary from year to year due to lack of mountain snowpack or reservoir storage. When seasonal limitations are known before annual investments are made for preparing and planting fields, operating costs can be adjusted for the anticipated water supply. Unexpected water supply limitations may occur during the season due to lack of precipitation, overestimate of the water supply, or failure of water delivery systems. Unanticipated in-season supply shortages limit the ability to adjust production costs but still allow water supply redistribution among crops and areas, such as abandoning planted fields or portions of fields to concentrate irrigation water on remaining land.

Deficit irrigation strategies have been studied in the western U.S. for over 100 years, beginning with studies of crop water requirements in the early 20th century (Mead and Johnson, 1900; Briggs and Shantz, 1913, 1914). Increases in our understanding of crop water requirements and crop responses to water stress since 1970 (Stewart and Hagan, 1973; Musick and Dusek, 1980; Doorenbos and Kassam, 1979; Hanks, 1983; Taylor et al., 1983; Howell, 1990) have led to proposed strategies to manage limited irrigation supplies (Barrett and Skogerboe, 1980; Hargreaves and Samani, 1984; Martin et al., 1989a; English, 1990; Hergert et al., 1993; Klocke et al., 2006; Fereres and Soriano, 2007; Martin et al., 2010; Kisseka et al., 2016; Rudnick et al., 2019; Trout and Manning, 2019; Expósito and Berbel, 2020; Fernández et al., 2020). The goal of this article is to build on that previous work and present a biophysical and economic analytical framework to evaluate the economic impacts of DI and apply the framework to western U.S. conditions. The primary cropping system considered is annual irrigated crops grown in semi-arid and arid environments. Although DI is also practiced in perennial tree and vine crops (Fereres and Soriano, 2007), these are not discussed because their response to water deficit is complex, varied, multi-seasonal, and not well quantified.

\section{Crop Water Productivity}

Knowledge of a crop's response to water is required to make rational DI management decisions. The crop water production function (WPF) describes the relationship between crop yield or value and the amount of water used. The basic WPF relates biomass produced to plant transpiration. Several early studies found that plant biomass increased nearly proportionally with the amount of water transpired relative to evaporative demand (e.g., de Wit, 1958). This was rationalized by concurrent $\mathrm{CO}_{2}$ assimilation and water vapor loss through open stomates. Because it is difficult to measure transpiration independent of soil water evaporation, and economic yield for many crops is based on grain, seed, fiber, or fruit production rather than total biomass, WPFs that relate economic yield to crop ET are commonly used in DI analysis. Howell (1990) presents a comprehensive summary of early WPF research and theory.

The WPF varies with the crop and variety, climate, soil, and management practices. A portion of the variability can be removed by normalizing the WPF for a crop and condition based on maximum (no water stress) ET (ETm) and maximum yield $(\mathrm{Ym})$, which usually occurs at ETm. With normalization, measured yield and ET data are divided by $\mathrm{Ym}$ and ETm, respectively, such that the normalized values range from 0 to 1 and the upper end of the WPF is 1,1 . This normalization is common in the WPF literature (e.g., Doorenbos and Kassam, 1979; Stewart et al., 1977). A normalized WPF is converted to an absolute WPF by multiplying the normalized yield by $Y m$ and the normalized ET by $\mathrm{ET} m$ for the crop and growing conditions. With normalization, WPF relationships can be compared among crops and conditions.

Most annual seed or fruit-bearing crops do not produce economic yield unless the ET exceeds a baseline amount. This threshold ET accounts for soil water evaporation and transpiration consumed while germinating and initiating growth of a plant capable of producing yield. Field studies have shown this pre-productive ET for many crops to be $20 \%$ to $50 \%$ of ETm (Stewart et al., 1977; Hanks, 1983; Trout and DeJonge, 2017). The ET required to initiate economic yield is the $x$-axis intercept of the WPF. Beyond the threshold ET, crop yield increases with increasing ET up to ETm (fig. 1). Additional water application beyond the full

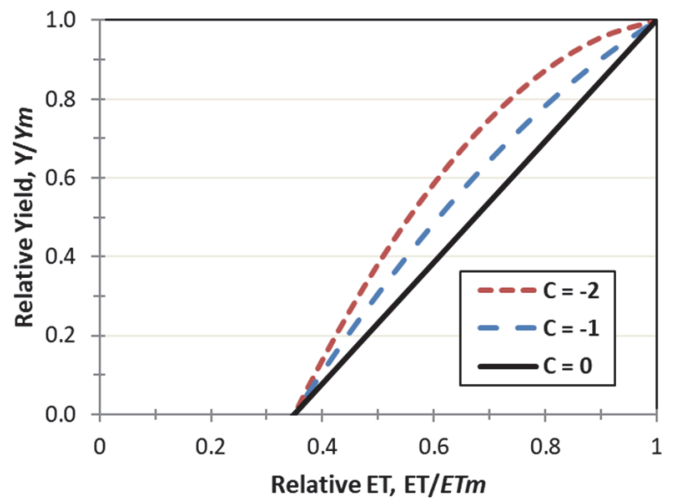

Figure 1. Normalized linear (solid line) and curvilinear (dashed lines) water production functions with 0.35 threshold relative ET. C values are the coefficient of the quadratic term of a second-degree polynomial. 
water requirement does not substantially increase ET and may decrease crop yield by decreasing root zone aeration and leaching of nutrients.

WPFs have been measured for many crops (Howell, 1990; Stewart and Hagan, 1973; Stewart et al., 1977; Hanks, 1983; Doorenbos and Kassam, 1979; Zwart and Bastiaanssen, 2004; Steduto et al., 2007; Trout and DeJonge, 2017). Many studies of field crops have concluded that the WPF is linear between the two end points (solid black line in fig. 1). The maximum crop water productivity (WP = $Y / E T$ ) for linear WPFs with a positive threshold (positive $x$ intercept) will always be at ETm.

Most crops that produce seed or fruits are more sensitive to water deficits during some growth stages than others. For example, maize is more sensitive to water stress during the reproductive and grain filling stages than during the vegetative stages (Steward and Hagan, 1973; Fereres and Soriano, 2007; Comas et al., 2019). This implies that the WPF is multivariate depending on when the water deficit is applied (Stewart et al., 1977) and that by applying water deficits first to the least sensitive (smallest yield loss) crop growth stages and last to the most sensitive stage, the WPF would be curvilinear, with increasing slope with increasing deficit (concave downward, blue and red dashed lines in fig. 1) (Hexem and Heady, 1978; Berck and Helfand, 1990; Trout and DeJonge, 2017). To achieve a concave WPF, the producer must know the sensitive growth stages and have the flexibility to strategically apply the seasonal water supply to avoid stress during critical stages. With a curvilinear WPF, DI may maximize WP.

When the irrigation water supply rate is fixed or is depleted early in the season, it may be impossible to avoid deficits during critical stages. If large deficits occur during critical stages, the yield will likely be less than that predicted by a WPF based on flexible water allocation (Comas et al., 2019). The WPF used to predict crop yield must be appropriate for the anticipated water supply conditions.

Use of ET as the independent variable in WPFs is recommended because yield is directly related to transpiration, which is the major component of ET. ET is also important to quantify the impact of irrigation on watershed hydrology and downstream water users because ET permanently removes water from the watershed (Grafton et al., 2018; Howell, 2001; Steduto et al., 2007). Some western states, such as Colorado, quantify water rights and water transfers based on ET such that water market prices are based on ET volumes (Varzi and Grigg, 2019). However, because irrigation water costs and limitations are commonly based on the water supply volume, the irrigation requirement to achieve a desired ET must also be estimated. The relationship between yield and irrigation amount is the irrigation water production function (IWPF).

Many studies have directly measured yield response to applied irrigation water. WPFs based on irrigation water applied vary with precipitation amount, soil characteristics, and irrigation application efficiency (the portion of the applied irrigation water that is stored in the root zone and consumed as ET) and are seldom valid for other locations or conditions. Rather than adopt a WPF based on water applied, it is preferable to measure or adopt an ET-based WPF and then estimate the irrigation water or total water supply required to achieve the desired level of ET based on local conditions.

Figure 2 illustrates a process for estimating the IWPF from an ET-based WPF. Water consumed as ET is provided by off-season precipitation, in-season precipitation, and irrigation. The portion of each of these sources that is stored in the root zone and contributes to ET is its effectiveness or efficiency. These efficiencies are generally high when the soil water content is low, because there is ample capacity to store water, and lowest when the soil water content is maintained near field capacity to achieve ETm. Because ET is also related to soil water deficit, the efficiencies can also be related to the relative ET. Water supply efficiencies tend to increase for the conditions under which the ET decreases. Trout and Manning (2019) presented quadratic relationships for these efficiencies based on the predicted efficiencies when the water supply is sufficient to achieve ETm, the ET level below which the efficiencies are $100 \%$ (no losses), and the degree of curvilinearity of the relationship. With these relationships, the irrigation supply needed to achieve the desired ET and yield can be calculated. In the example shown in figure 2, when the water supply is adequate to achieve ETm, the storage efficiency of off-season precipitation is $40 \%$, the effectiveness of in-season precipitation is $70 \%$, and the irrigation application efficiency is $75 \%$. All three efficiencies increase to $100 \%$ when ET is below $50 \%$ of ETm.

In figure 2, the WPF is assumed linear between an ETm of $630 \mathrm{~mm}$ and threshold ET of $220 \mathrm{~mm}$. The in-season precipitation is $300 \mathrm{~mm}$, and up to $75 \mathrm{~mm}$ of off-season precipitation can be stored in the root zone for crop use. This 375 $\mathrm{mm}$ is nearly all (98\%) effective under this rainfed condition and, according to the WPF, produces a rainfed yield of $36 \%$ of $Y m$. However, when irrigation is added to achieve greater ET and yield, some of the in-season precipitation is lost to

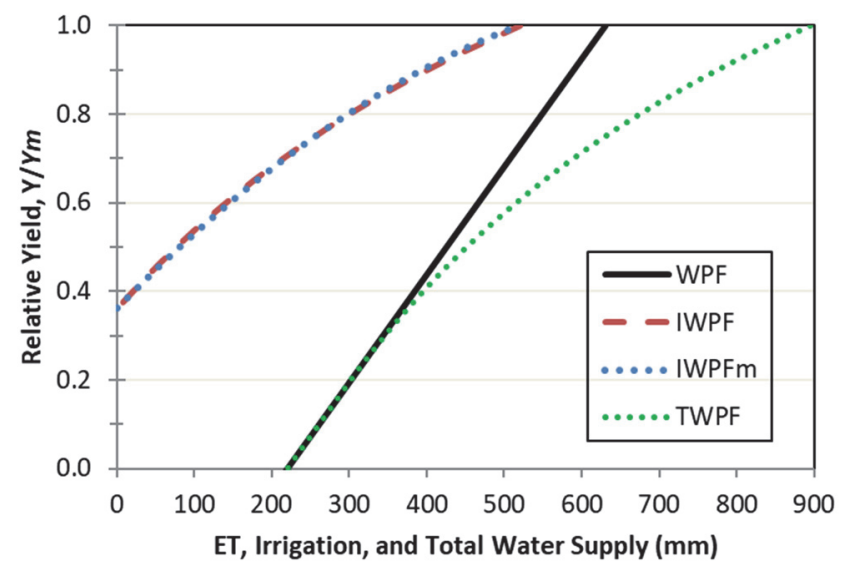

Figure 2. Water production functions based on a linear WPF (solid black line) with ET $m=630 \mathrm{~mm}$ and threshold ET $=220 \mathrm{~mm}$. The irrigation water production function (IWPF, red dashed line) and total water production function (TWPF, green dashed line) are based on 300 $\mathrm{mm}$ of seasonal precipitation, $75 \mathrm{~mm}$ of storable off-season precipitation, and $75 \%$ irrigation efficiency at ET $m$ and assume that soil water storage, precipitation effectiveness, and irrigation efficiency are $100 \%$ at $50 \%$ of ET $m$ and decrease quadratically with increasing ET. Blue dotted line is a quadratic equation fit to the IWPF. The parameters used in these relationships are given in table A1 in the Appendix; the spreadsheet-based model used to create this figure is available at: http://dx.doi.org/10.15482/USDA.ADC/1518761. 
runoff or deep percolation, and there is less depletion of the pre-season soil water at the end of the season (and less capacity to store off-season precipitation for the following season), so the effectiveness of the precipitation decreases. In the figure 2 example, when enough irrigation water is applied to achieve ETm (full irrigation), only $210 \mathrm{~mm}$ of the in-season precipitation (70\%) is used for ET and only $30 \mathrm{~mm}$ of the off-season storage (40\%) is consumed. This results in a deficiency to be met with irrigation of $390 \mathrm{~mm}$ at ETm. The amount of irrigation water that must be applied to meet the deficiency and achieve the target ET (red dashed line) must be greater than the deficiency because of irrigation water losses. The figure shows a full irrigation application requirement of $520 \mathrm{~mm}$ to meet the $390 \mathrm{~mm}$ deficiency $(75 \%$ efficiency).

The parameters used to generate the curves shown in figure 2 are given in table A1 in the Appendix. The resulting IWPF can be modeled by a quadratic relationship (English, 1990; Martin et al., 1989b) derived in the Appendix and shown as a blue dotted line in figure 2, or by other diminishing return functions, such as a Cobb-Douglas power curve relationship (Hexem and Heady, 1978; Martin et al., 1989a).

The sum of potential off-season storage, in-season precipitation, and irrigation is the total water supply (green dotted line). The parallel IWPF and TWPF relationships are flatter and more curvilinear than the WPF (Stewart and Hagan, 1973; Barrett and Skogerboe, 1980; Martin, 1989a). In this example, $900 \mathrm{~mm}$ of total water supply is required to achieve $630 \mathrm{~mm}$ of ETm.

The maximum irrigation water productivity (yield per unit irrigation water applied) is when rainfed yield is produced with no irrigation (e.g., $36 \%$ of maximum yield is produced with no irrigation in fig. 2). If rainfed yield were 0 , the maximum irrigation water productivity would depend on the shape of the IWPF. The maximum water productivity based on total water supply depends on the shape of the TWPF. In figure 2, the maximum WP based on total water supply is when $74 \%$ of the maximum yield is produced with $245 \mathrm{~mm}$ of irrigation applied, and $245+375=620 \mathrm{~mm}$ of total water supply. The maximum WP for a WPF is the point on the WPF curve where the tangent passes through the origin.

\section{NET INCOME WITH DEFICIT IRRIGATION}

The amount of irrigation that maximizes water productivity seldom provides the maximum net income (NI) for the producer. An economic analysis of revenue and costs is required to determine whether and what amount of DI maximizes NI. Martin et al. (1989a) and English (1990) describe an analytical framework for economic analysis of DI and point out the important difference between land-limiting and water-limiting conditions.

\section{ADEQUATE IRRIGATION SUPPLY FOR THE AVAILABLE LAND}

When the water supply is adequate to fully irrigate the land, such as where groundwater is plentiful and pumping is not restricted, water rights and/or storage are adequate for full irrigation, or water markets enable purchasing water as needed, the irrigation depth (volume per unit area) that produces maximum NI is the depth for which the marginal revenue (yield times price) is equal to the marginal costs (cost of water and other variable production costs). When the NI with irrigation is greater than the NI without irrigation (rainfed), all the land should be irrigated, and the objective is to maximize NI per unit of land (Martin et al., 1989a; English, 1990).

The net income per unit area (NI, $\left.\$ \mathrm{ha}^{-1}\right)$ is calculated considering both revenue and costs:

$$
\begin{aligned}
\mathrm{NI} & =p_{Y i} f(I)-c_{i} I-c_{Y i} f(I)-c_{A i} \\
& =\left(p_{Y i}-c_{Y i}\right) f(I)-c_{i} I-c_{A i}
\end{aligned}
$$

where

$$
p_{Y i}=\text { price of irrigated crop }\left(\$ \mathrm{~kg}^{-1}\right)
$$

$f(I)=$ yield calculated from IWPF $\left(\mathrm{kg} \mathrm{ha}^{-1}\right)$

$I=$ amount of irrigation water applied $\left(\mathrm{m}^{3} \mathrm{ha}^{-1}, 1 \mathrm{~m}^{3} \mathrm{ha}^{-1}\right.$ $=0.1 \mathrm{~mm}$ depth)

$c_{i}=$ variable cost of acquiring and applying irrigation water $\left(\$ \mathrm{~m}^{-3}\right)$

$c_{Y i}=$ yield-based variable cost of producing the irrigated crop excluding irrigation costs $\left(\$ \mathrm{~kg}^{-1}\right)$

$c_{A i}=$ fixed or sunk costs of producing the irrigated crop $\left(\$\right.$ ha $\left.^{-1}\right)$.

This formulation includes three costs of production: the variable cost of acquiring and applying irrigation water (e.g., water purchase cost, pump power costs, irrigation labor costs, irrigation system maintenance costs), the variable cost associated with the target irrigated yield (e.g., seed, fertilizer, harvest), and the fixed costs associated with growing an irrigated crop (e.g., land, facilities, equipment including irrigation equipment, and land preparation and cropping costs) (English et al., 1990). We assume that the variable costs are proportional to the water use and anticipated yield, and the revenue is proportional to the yield.

The NI for an unlimited water supply is maximized when the derivative of the NI with respect to $I$ is equal to zero:

$$
\begin{gathered}
\frac{d(\mathrm{NI})}{d I}=\left(p_{Y i}-c_{Y i}\right) f^{\prime}(I)-c_{i}=0 \\
\left(p_{Y i}-c_{Y i}\right) f^{\prime}(I)=c_{i}
\end{gathered}
$$

where $f^{\prime}(I)=d Y / d I$, the derivative of the IWPF.

Equation 3 shows that the NI is maximum when the marginal revenue (yield price minus variable yield costs, times the marginal yield) is equal to the marginal water cost. Fixed costs impact NI but not the irrigation amount that maximizes NI. The irrigation amount that satisfies equation $3\left(I_{o p}\right)$ provides the maximum $\mathrm{NI}\left(\mathrm{NI}_{M}\right)$. In regions with economically viable rainfed yields, the NI may also be posed in terms of the economic return to irrigation, in which case $f(I)$ would represent the yield increase due to irrigation, and the fixed costs would be based on cost increases compared to rainfed production. This approach will derive the same $I_{o p}$ as above.

The marginal yield, $f^{\prime}(I)$, is the slope of the IWPF at an irrigation amount. As English (1990) points out, the IWPF 
can be modeled by a quadratic equation, for which the derivative is easily derived. Figure 2 shows a quadratic relationship that closely models the IWPF. For a quadratic IWPF of the form $f(I)=k_{0}+k_{1} I+k_{2} I^{2}$, for which $f^{\prime}(I)=k_{1}+2 k_{2} I, I_{o p}$ can be derived directly:

$$
I_{o p}=\left(\frac{1}{2 k_{2}}\right)\left(\frac{c_{i}}{\left(p_{Y i}-c_{Y i}\right)}-k_{1}\right)
$$

The Appendix provides a process for estimating a quadratic IWPF based on the rainfed yield $\left(k_{0}\right)$, the irrigation amount required to produce ET $m(\mathrm{Im})$, and the degree of curvilinearity of the IWPF. The quadratic IWPF equation is only valid for $I \leq I m$. Martin et al. (1989a) derived a similar direct $I_{o p}$ solution for a Cobb-Douglas (power curve) IWPF.

\section{INADEQUATE IRRIGATION SUPPLY FOR THE AVAILABLE LAND}

When the water supply is inadequate to fully irrigate the available land and additional water cannot be acquired, the producer must decide whether to fully irrigate a portion of the land or to deficit irrigate and spread the available water across more land. We assume that the water cost is less than the marginal revenue, so all the available water will be used.

In this limited water condition, the goal is to maximize the value of the available water by maximizing the NI from all the land. The NI is maximized when the marginal value of the water saved through DI is equal to the value gained by using the saved water to irrigate additional land (Barrett and Skogerboe, 1980; English, 1990; English et al., 1990). Revenue from alternative rainfed production or fallow maintenance costs on the unirrigated land must be considered.

The NI equation for this case is the sum of the NI from the irrigated land $\left(\mathrm{NI}_{i}\right)$ and the $\mathrm{NI}$ from the unirrigated land $\left(\mathrm{NI}_{r}\right)$. The NI for the total area is:

$$
\begin{aligned}
\mathrm{NI} & =\mathrm{NI}_{i}+\mathrm{NI}_{r} \\
& =\left(p_{Y i} f(I)-c_{i} I-c_{Y i} f(I)-c_{A i}\right) A_{i} \\
& +\left(p_{Y r} Y_{r}-c_{y r} Y_{r}-c_{A r}\right) A_{r} \\
& =\left(\left(p_{Y i}-c_{Y i}\right) f(I)-c_{i} I-c_{A i}\right) A_{i} \\
& +\left(\left(p_{Y r}-c_{y r}\right) Y_{r}-c_{A r}\right) A_{r}
\end{aligned}
$$

where

$p_{Y r}=$ price of the yield on the unirrigated land $\left(\$ \mathrm{~kg}^{-1}\right)$

$Y_{r}=$ yield on the unirrigated land under rainfed conditions $\left(\mathrm{kg} \mathrm{ha}^{-1}\right)$

$c_{y r}=$ variable production cost of unirrigated crop related

to expected yield $\left(\$ \mathrm{~kg}^{-1}\right)$

$c_{A r}=$ fixed or sunk costs of production of unirrigated crop $\left(\$ \mathrm{ha}^{-1}\right)$

$A_{i}=$ area irrigated (ha)

$A_{r}=$ area unirrigated (ha).

For the unirrigated land, there is no water cost and, for planning purposes, the projected yield $\left(Y_{r}\right)$ is estimated based on the anticipated rainfed yields in the region. Equation 5 allows the fixed production costs per unit area on the irrigated land $\left(c_{A i}\right)$ to be different from the costs on the rainfed land $\left(c_{A r}\right)$. The NI per unit area on the unirrigated land, $\left(p_{Y r}\right.$ $\left.-c_{y r}\right) Y_{r}-c_{A r}$, can be positive if the rainfed crop revenue exceeds the production costs or negative if the income is less than the production costs, as would be the case if the unirrigated land were fallowed but still incurred maintenance costs, such as for weed management. The parameters in equation 5 are constrained by two limits:

$$
\begin{gathered}
I \leq \frac{W}{A_{i}} \\
A_{i}+A_{r} \leq A_{T}
\end{gathered}
$$

where $W$ is the total water supply $\left(\mathrm{m}^{3}\right)$, and $A_{T}$ is the total land available (ha).

When equations 6 and 7 are substituted into equation 5 and all the land and water are used:

$$
\begin{aligned}
\mathrm{NI} & =\left(\left(p_{Y i}-c_{Y i}\right) f\left(\frac{W}{A_{i}}\right) A_{i}-c_{i}(W)-c_{A i} A_{i}\right) \\
& +\left(\left(p_{Y r}-c_{y r}\right) Y_{r}-c_{A r}\right)\left(A_{T}-A_{i}\right)
\end{aligned}
$$

As previously, the area irrigated, and thus the irrigation depth, that maximizes NI is where the derivative of equation 8 is equal to 0 . Assume that $Y_{r}, A_{T}$, and $W$ are constants.

$$
\begin{aligned}
\frac{d(\mathrm{NI})}{d\left(A_{i}\right)} & =\left(\left(p_{Y i}-c_{Y i}\right)\left[f\left(\frac{W}{A_{i}}\right)-A_{i} f^{\prime}\left(\frac{W}{A_{i}}\right) \frac{W}{A_{i}^{2}}\right]-c_{A i}\right) \\
& -\left(\left(p_{Y r}-c_{y r}\right) Y_{r}-c_{A r}\right) \\
& =0 \\
\left(p_{Y i}-c_{Y i}\right)\left[f\left(\frac{W}{A_{i}}\right)-\left(\frac{W}{A_{i}}\right) f^{\prime}\left(\frac{W}{A_{i}}\right)\right]-c_{A i} & =\left(\left(p_{Y r}-c_{y r}\right) Y_{r}-c_{A r}\right)
\end{aligned}
$$

where $f\left(\frac{W}{A_{i}}\right)$ and $f^{\prime}\left(\frac{W}{A_{i}}\right)$ are the IWPF and its derivative, respectively. Equation 10 differs from that developed by English (1990) and Barrett and Skogerboe (1980) in that it includes variable production costs related to yields, and revenue and costs on the unirrigated land. Rearranging equation 10 to separate the terms dependent on irrigation amount (left side) from the constant price and cost terms and substituting $I=W / A_{i}$ gives:

$$
\begin{aligned}
& f(I)-(I) f^{\prime}(I)= \\
& \left(c_{A i}+\left(p_{Y r}-c_{y r}\right) Y_{r}-c_{A r}\right) /\left(p_{Y i}-c_{Y i}\right)
\end{aligned}
$$

As above, if $f(I)$ can be represented by a quadratic equation, an analytical solution for equation 11 can be derived. Substituting $f(I)=k_{0}+k_{1} I+k_{2} I^{2}$ and $f^{\prime}(I)=k_{1}+2 k_{2} I$ into equation 11: 


$$
\begin{aligned}
& {\left[\left(k_{0}+k_{1} I+k_{2} I^{2}\right)-I\left(k_{1}+2 k_{2} I\right)\right]=} \\
& \left(c_{A i}+\left(p_{Y r}-c_{y r}\right) Y_{r}-c_{A r}\right) /\left(p_{Y i}-c_{Y i}\right)
\end{aligned}
$$

Solving equation 12 for $I$ gives the irrigation amount $\left(I_{o p}\right.$, $\left.\mathrm{m}^{3} \mathrm{ha}^{-1}\right)$ and the irrigated area $\left(W / I_{o p}\right.$, ha) that maximize NI.

$$
I_{o p}=\sqrt{\left[\left(\frac{1}{k_{2}}\right)\left(k_{0}-\frac{c_{A i}+\left(p_{Y r}-c_{y r}\right) Y_{r}-c_{A r}}{\left(p_{Y i}-c_{Y i}\right)}\right)\right]}
$$

The lower limit of $I_{o p}$ is the irrigation amount when water is allocated to the whole area $\left(W / A_{T}\right)$, and the upper limit is the amount that maximizes ET (Im). Assuming all the irrigation water is used, the lower limit of $A_{i}$ is W/Im.

\section{In-Season Reduced Irrigation Supply}

Once cropping decisions have been made, if the irrigation water supply is reduced during the season below the pre-season anticipated supply, a decision on how to allocate the remaining supply on the irrigated area must be made. As above, options are to spread the remaining water on the previously irrigated area $\left(A_{i}\right)$ or to concentrate the water on a portion of $A_{i}$. The NI equation for this case is similar to equation 8 except that the total area considered is now the previously irrigated area, and the yield on any portion of that area left unirrigated for the remainder of the season is based on irrigation already received. If we assume that all land-based production costs have been expended, they can be combined into one sunk cost $\left(c_{a i} A_{i}\right)$.

$$
\begin{aligned}
\mathrm{NI} & =\left(\left(p_{Y i}-c_{Y i}\right) f\left(\frac{W_{o}}{A_{i}}+\frac{W_{2}}{A_{i 2}}\right) A_{i 2}-c_{i} W_{2}\right) \\
& +\left(p_{Y i}-c_{Y i}\right) Y_{i o}\left(A_{i}-A_{i 2}\right)-c_{a i} A_{i} \\
& =\left(p_{Y i}-c_{Y i}\right)\left[\left(f\left(\frac{W_{o}}{A_{i}}+\frac{W_{2}}{A_{i 2}}\right)-Y_{i o}\right) A_{i 2}\right. \\
& \left.+Y_{i o} A_{i}-c_{i} W_{2}-c_{a i} A_{i}\right]
\end{aligned}
$$

where

$W_{o}=$ amount of irrigation water already applied to area

$$
A_{i}\left(\mathrm{~m}^{3}\right)
$$

$W_{2}=$ remaining in-season water supply $\left(W_{o} \leq W_{2} \leq W\right)$ $\left(\mathrm{m}^{3}\right)$

$A_{i 2}=$ area that will continue to be irrigated $\left(A_{i 2} \leq A_{i}\right)$ (ha)

$Y_{i o}=$ expected yield with no additional irrigation $\left(\mathrm{kg} \mathrm{ha}^{-1}\right)$.

Substituting $I_{o}=\left(\frac{W_{o}}{A_{i}}\right), I_{2}=\left(\frac{W_{2}}{A_{i 2}}\right)$, and $\left(\frac{W_{2}}{I_{2}}\right)=A_{i 2}$ into equation 14 and rearranging, the NI equation becomes:

$$
\begin{aligned}
\mathrm{NI} & =\left(p_{Y i}-c_{Y i}\right)\left[\left(\frac{f\left(I_{o}+I_{2}\right)-Y_{i o}}{I_{2}}\right) W_{2}\right. \\
& \left.+Y_{i o}\left(A_{i}\right)-c_{i} W_{2}-c_{a i} A_{i}\right]
\end{aligned}
$$

The only term in equation 15 that varies with $A_{i 2}$ is $\left(f\left(I_{o}+I_{2}\right)-Y_{i o}\right) / I_{2}$. This term represents the yield increase per unit of additional water applied. Because the slope of the IWPF decreases with increasing irrigation (diminishing returns), the minimum $I_{2}$, or equivalently the maximum $A_{i 2}$, maximizes NI. Thus, NI is maximized by spreading the remaining irrigation water across all the originally irrigated area such that $A_{i 2}=A_{i}$. This result assumes that there is enough water available to initiate yield (avoid total crop failure) on the whole irrigated area and that the IWPF is concave downward. Inherent in this assumption is that the remaining water can be applied when it would be most productive.

An equivalent situation is when supplemental irrigation is used to reduce the risk of yield loss. Because land-based production costs have been expended (sunk costs) with supplemental irrigation, when precipitation is inadequate to maximize yield, supplemental irrigation maximizes NI when spread across all irrigatable land.

\section{SCENARIOS}

The NI relationships presented above are programmed in a spreadsheet downloadable from the USDA National Ag Library Ag Data Commons (http://dx.doi.org/10.15482/ USDA.ADC/1518761). Price, cost, and production function parameters can be varied to calculate NI and $I_{o p}$ for relevant conditions. The following scenarios are based on the parameters listed in tables A1 and A2 in the Appendix.

\section{DEFICIT IRRIGATION MANAGEMENT WITH \\ UNLIMITED BUT HIGH-COST WATER}

When the cost of water is high relative to the value of the crop grown, DI may increase NI. Depending on the source, agricultural water prices in the western U.S. vary widely from about $\$ 0.03 \mathrm{~m}^{-3}$ to over $\$ 0.50 \mathrm{~m}^{-3}$. Equations 1 to 4 can be used evaluate DI planning strategies with unlimited but expensive water supplies.

Figure 3 shows a scenario with a water supply variable cost of $\$ 0.15 \mathrm{~m}^{-3}$, a maize crop priced at $\$ 0.20 \mathrm{~kg}^{-1}$, and

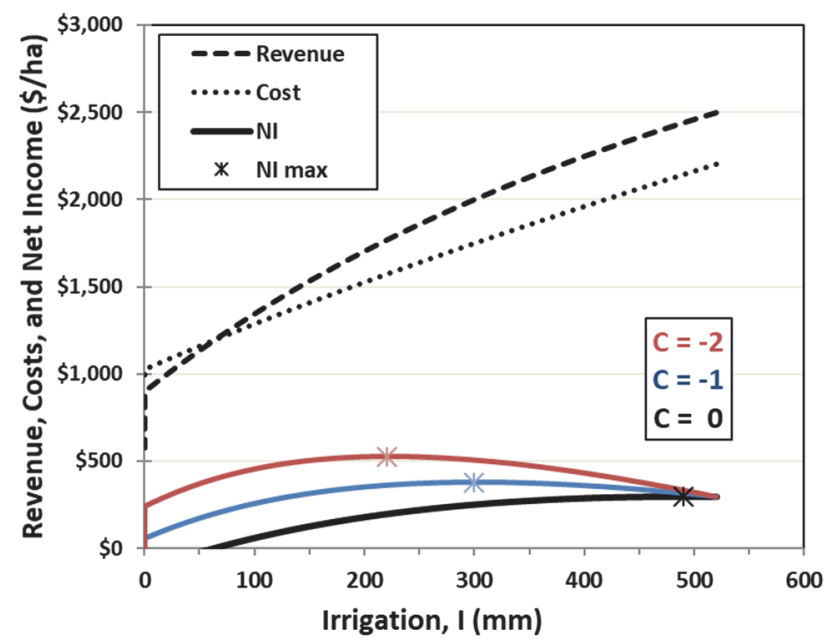

Figure 3. Revenue, cost, and net income (NI) as a function of applied irrigation for a linear WPF and the parameters in table A2 in the Appendix (black lines). Cross represents $I_{o p}$ and $\mathrm{NI}_{M}$. Blue line represents NI for slightly curvilinear WPF $(C=-1)$. Red line represents NI for a substantially curvilinear WPF $(C=-2)$. 
typical U.S. Central Plains yields and production costs (table A2). The production cost curve shown assumes that the producer plans for DI and reduces variable production costs according to anticipated yield. Full irrigation (Im) for these conditions is $520 \mathrm{~mm}$. For a linear WPF $(C=0)$, nearly full irrigation $(490 \mathrm{~mm})$ maximizes NI. Because the revenue and cost curves are nearly parallel for moderate irrigation deficits, the NI variation with up to a $30 \%$ deficit is only $10 \%$. For the IWPF shown in figure 2, a $30 \%$ irrigation deficit results in only a $10 \%$ reduction in crop ET because the irrigation and precipitation use efficiencies increase with DI.

For the linear WPF and these conditions, $I_{o p}$ would equal $I m$ for irrigation application efficiencies greater than 0.77. If the irrigation efficiency is lower, more water would be required to achieve a level of ET and yield, making water more expensive and reducing NI and $I_{o p}$. If precipitation were greater, less irrigation water would be required, so NI would increase, but the relative level of DI $\left(I_{o p} / I m\right)$ to maximize NI would increase only a small amount. The deficit that maximizes NI is sensitive to prices and other factors that change the slope of either the revenue or cost function. Low crop price relative to high water cost favors DI. For example, a water cost increase from $\$ 0.15$ to $\$ 0.25 \mathrm{~m}^{-3}$ decreases $I_{o p}$ from 490 to $310 \mathrm{~mm}$ and decreases $\mathrm{NI}_{\mathrm{M}}$ from $\$ 300$ to $\$ 100 \mathrm{ha}^{-1}$.

If the WPF is more curvilinear, the IWPF is also more curvilinear, and $I_{o p}$ decreases from $490 \mathrm{~mm}$ for the linear WPF to $300 \mathrm{~mm}$ for a WPF with slight curvilinearity $(C=-$ 1) and to $220 \mathrm{~mm}$ for a substantially curved WPF, $(C=-2)$. With DI, NI increases when the IWPF is more curvilinear because the ET is used more productively and more yield is produced with the same amount of irrigation water.

For all cases, the NI relationship is fairly flat near $I_{o p}$, and thus NI is insensitive to as much as $100 \mathrm{~mm}$ irrigation deviations from $I_{o p}$. The relative insensitivity is because water and other production costs increase as yield and revenue increase.

A producer may have two or more sources of irrigation water that have different costs. Inexpensive water would normally be used before more expensive water. In this case, the slope of the cost function would be discontinuous, and the irrigation amount that maximizes NI would be calculated for each water cost.

In rapidly growing urban areas of the western U.S., such as California, western Nevada, central Arizona, and the front range of Colorado, population growth has resulted in water shortages and active water markets. Even though the cost of a surface water supply for producers may be small, the value of the water for other uses may be much greater, and producers may have the opportunity to lease or sell water. If leasing or selling water for other uses is an option, the water has both acquisition and application costs, and potential revenue is based on the opportunity cost to lease or sell all or a portion of the water supply. In this case, the amount leased reduces the water supply for irrigation but becomes a second revenue commodity. Trout and Manning (2019) present NI maximization relationships for this condition.

\section{DEFICIT IRRIGATION MANAGEMENT WITH \\ Restricted Seasonal PuMPing}

In much of the irrigated area within the U.S. Great Plains, irrigation water is pumped from underground aquifers. Portions of the High Plains aquifer that underlies areas of $\mathrm{Ne}-$ braska, western Kansas, north-central Texas, and eastern Colorado are being depleted (McGuire, 2017). To sustain the aquifer, state-authorized regional authorities, such as Natural Resource Districts in Nebraska, Groundwater Management Districts in Kansas, and Groundwater Conservation Districts in Texas, have enacted limitations on groundwater pumping. For example, 12 of the 23 Natural Resource Districts in Nebraska have enacted groundwater pumping allocations in at least portions of their districts (NARD, 2019). Pumping restrictions are also being promulgated for groundwater basins in California under the Sustainable Groundwater Management Act (CDWR, 2020).

Groundwater pumping restrictions in these areas are typically based on the volume of water that can be pumped per unit of irrigated area. For example, a common allowance in western Nebraska is $1500 \mathrm{~mm}$ depth over five years or an average of $300 \mathrm{~mm}\left(3000 \mathrm{~m}^{3} \mathrm{ha}^{-1}\right)$ per year (NARD, 2019). Under this restriction, producers know their irrigation supply each season and have flexibility to schedule applications. Similar limited water conditions may also occur with surface water supplies sourced from mountain snowpack and reservoir storage for which seasonal supply deficits are known prior to planting.

In many of the managed groundwater areas in the Great Plains, rainfall plus the pumping allocation may not meet full water requirements in most years. Producers are faced with deciding how to allocate the irrigation water to the available land, i.e., whether to spread the water across the whole irrigated area or concentrate the water on a portion of the area. In much of the Great Plains, rainfed production is economically viable, although less profitable than irrigated production, so irrigation management planning entails deciding how much land to irrigate and what crops to grow. The main unknown is the amount and timing of precipitation.

When water is the limiting resource, the goal is to maximize NI per unit of available irrigation water supply. The amount of land irrigated, or equivalently, the irrigation depth on the irrigated land, that maximizes NI can be calculated with equations 10 or 11 or estimated by equation 13 . The irrigation depth that maximizes NI will be between the depth determined under unlimited water conditions, which is usually full irrigation (concentrated allocation), and the water supply divided by the total area (spread allocation). If the remaining land can produce a profitable rainfed crop without irrigation, the net returns from the rainfed portion of the land must be considered.

Figure 4 shows how the NI varies with relative area irrigated $\left(A_{i} / A_{T}\right)$ for a Central Plains maize crop that has a 300 $\mathrm{mm}$ annual pumping limit, receives $300 \mathrm{~mm}$ of seasonal precipitation, and can store up to $75 \mathrm{~mm}$ of off-season precipitation, as might be the case in western Nebraska and Kansas. In the example, the unirrigated portion of the land is cropped to rainfed maize, and the rainfed yield is projected based on the $y$-intercept of the IWPF (yield with no irrigation). 


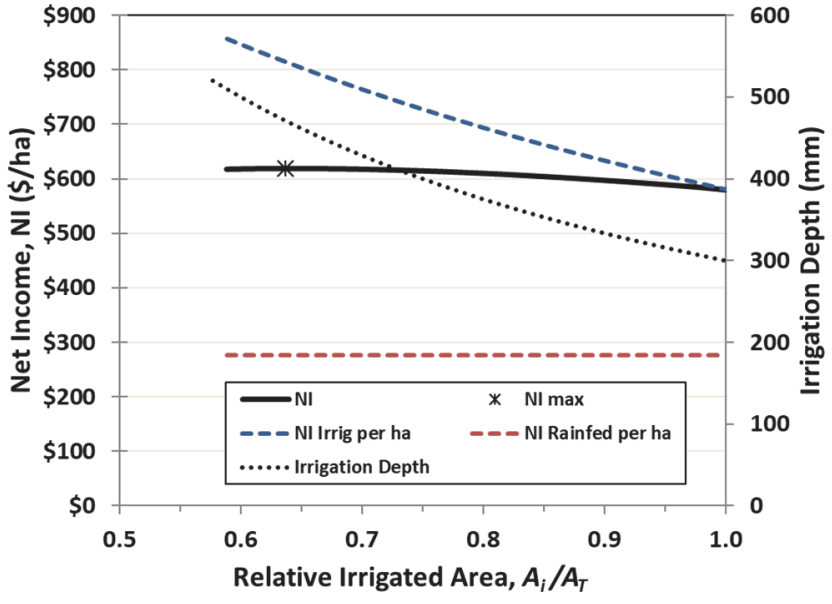

Figure 4. Net income (NI) versus relative irrigated area for a maize crop in the Great Plains. Solid line is the NI; cross is $\mathrm{NI}_{M}$ at $I_{o p}$. Dashed blue and red lines are the irrigation and rainfed NI, respectively, on a per unit area basis. Dotted line is the irrigation depth associated with the relative area. Parameters are given in table $\mathrm{A} 2$ in the Appendix.

At full irrigation $(520 \mathrm{~mm}), 58 \%$ of the land would be irrigated with an NI on the irrigated land of $\$ 870 \mathrm{ha}^{-1}$ and on the rainfed land of $\$ 275 \mathrm{ha}^{-1}$ giving an average NI for all the land of $\$ 617 \mathrm{ha}^{-1}$. If all the land were irrigated, the irrigation depth would be $300 \mathrm{~mm}$ (the allocation) so the deficit would be $220 \mathrm{~mm}$ and the NI would be $\$ 580 \mathrm{ha}^{-1}$. The optimum irrigation depth and relative irrigated area are $470 \mathrm{~mm}$ and 0.64 with an average NI for all the land of $\$ 618 \mathrm{ha}^{-1}$. Similar to the previous unlimited water case, when the production costs are appropriate for the projected yield, the NI is relatively insensitive to the decision whether to concentrate the water or deficit irrigate a larger portion of the area, so the producer can consider factors or risks beyond those included in the NI model without greatly jeopardizing NI. Martin et al. (1989a) also concluded NI may be relatively insensitive to area irrigated.

Figure 5 , based on equation 11 , illustrates the impact of the income and costs on the unirrigated portion of the land on $I_{o p}$. The dotted line in figure 5 represents the right side of

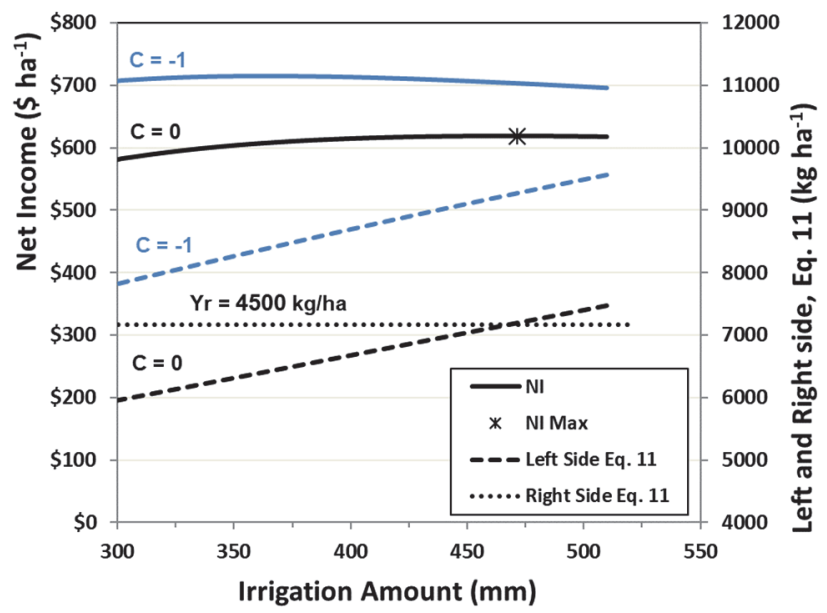

Figure 5. Net income (NI) as a function of irrigation amount ( $I$ ) for the water-limited scenario. Solid lines are NI for linear (black) and slightly curvilinear (blue, $C=-1$ ) WPFs. Dashed lines represent the left side of equation 11, which is dependent on IWPF. Dotted line represents the right side of equation 11 with a rainfed yield of $4500 \mathrm{~kg} \mathrm{ha}^{-1}$. equation 11 which includes income per unit area from the unirrigated land $\left(\left[p_{Y r}-c_{y r}\right] Y_{r}\right)$ and the difference in fixed costs between irrigated and unirrigated land $\left(c_{A i}-c_{A r}\right)$. Because these factors do not vary with irrigation amount, the dotted line is horizontal. The dashed lines represent the left side of equation 11 which is a function of the irrigation amount and the IWPF. The irrigation amount where the dashed and dotted lines cross is $I_{o p}$, as shown on the NI curve (solid line). The black lines in figure 5 are for the linear WPF (with parameters from table A1) with the rainfed yield predicted by the IWPF as $4500 \mathrm{~kg} \mathrm{ha}^{-1}$. For this case, $I_{o p}$ is 470 $\mathrm{mm}$, equivalent to 0.64 relative area, as was also shown in figure 4 .

For an IWPF that increases with $I$ at a decreasing rate (concave downward), the left side of equation 11 (dashed line) always has a positive slope. Thus, greater rainfed yield, which increases the value of the right side (dotted line), increases $I_{o p}$ and decreases $A_{i}$. Rainfed yields greater than 4900 $\mathrm{kg} \mathrm{ha}^{-1}$ with the assumed prices and costs result in a rightside value greater than $7500 \mathrm{~kg} \mathrm{ha}^{-1}$ and thus would maximize NI with full irrigation $(520 \mathrm{~mm})$ on $58 \%$ of the land. Increasing production costs for the irrigated crop $\left(c_{A i}\right)$ similarly raise the right-side value and increase $I_{o p}$. At the other extreme, rainfed yield below $3200 \mathrm{~kg} \mathrm{ha}^{-1}$ would favor spreading the $300 \mathrm{~mm}$ water supply evenly across all the land.

In regions where precipitation is not adequate for economic rainfed yields, the right side of equation 11 simplifies to $\left(c_{A i}-c_{A r}\right) /\left(p_{Y i}-c_{Y i}\right)$. For the parameters in table $\mathrm{A} 2$, if the fixed costs of the irrigated land exceed the fixed costs of the unirrigated land by less than $\$ 1100 \mathrm{ha}^{-1}$, spreading the available irrigation water across all the available land maximizes NI. If $\left(c_{A i}-c_{A r}\right)$ exceeds $\$ 1330 \mathrm{ha}^{-1}$, concentrating the water by fully irrigating to minimize irrigated land costs maximizes NI. The $I_{o p}$ is sensitive to relatively small changes in rainfed yield and fixed production costs, as illustrated by the relatively small slope of the left side of equation 11 . Conversely, if production costs are appropriate for the projected yield, NI is relatively insensitive to the portion of the area irrigated, so selecting an irrigation amount other than $I_{o p}$ has little impact on NI.

The blue lines in figure 5 are for a slightly curvilinear WPF relationship $(C=-1)$ for which the predicted irrigated yield and NI under DI increase. Because the left side of equation 11 increases, the rainfed yields required to favor concentrating of the water on smaller portions of the land also increase. For this IWPF, rainfed yields must exceed $6900 \mathrm{~kg}$ $\mathrm{ha}^{-1}$ to favor fully irrigating $58 \%$ of the area, while rainfed yields below $5200 \mathrm{~kg} \mathrm{ha}^{-1}$ favor spreading the water on all the land.

Barrett and Skogerboe (1980) point out that, for the limited water scenario, although NI increases with irrigation efficiency, $I_{o p}$ and the area irrigated remain relatively constant. Increased irrigation efficiency increases both $f(I)$ and $f^{\prime}(I)$ with little net effect on the magnitude or slope of the left side of equation 11 and thus little effect on $I_{o p}$. However, increasing efficiency decreases $I m$ because water losses decrease, which decreases the deficit $\left(1-I_{o p} / I m\right)$ and results in an increase in irrigated yield and NI. For the parameters used in the figures, when irrigation efficiency exceeds $0.81, I_{o p}=I m$. 


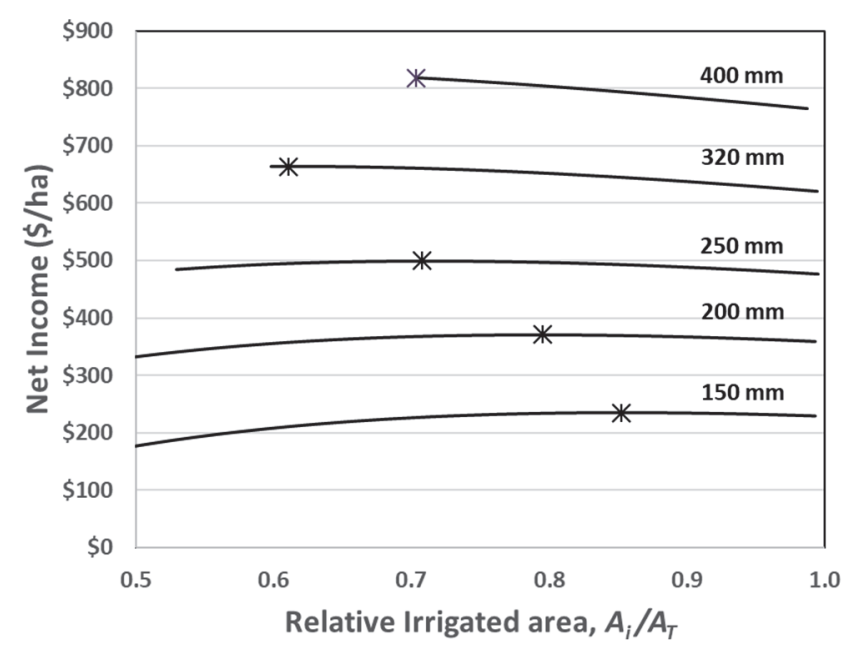

Figure 6. Net income (NI) as a function of relative irrigated area with a limited water supply and rainfed cropping. Lines show the NI for range of in-season precipitation amounts. Crosses show $I_{o p}$ and $\mathrm{NI}_{M}$ for each precipitation amount.

Assuming irrigation does not exceed $I m$, irrigation efficiency greater than 0.81 results in increased area irrigated.

The greatest uncertainty with DI planning is precipitation. Although the producer controls management practices and can anticipate input costs and yield prices, yields and NI also depend on precipitation. However, if the unirrigated land is cropped, because precipitation affects yields of both the irrigated and rainfed crops, variation in precipitation does not have a large effect on the decision of how much of the land to irrigate. Figure 6 shows NI for a range of in-season precipitation amounts for the parameters used in figures 4 and 5. In-season precipitation of $320 \mathrm{~mm}$ maximizes NI when full irrigation is applied to $58 \%$ of the area. With only 150 $\mathrm{mm}$ of precipitation, NI is maximized when the water supply is spread across $85 \%$ of the area. The increase in irrigated area with decreasing precipitation is because rainfed yield is more sensitive to precipitation than irrigated yield. If precipitation exceeds $320 \mathrm{~mm}, \mathrm{Im}$ decreases, so the area that can be irrigated with full irrigation increases. Although NI is sensitive to precipitation amount, $\mathrm{NI}$ is insensitive to the portion of the field irrigated with the limited irrigation water supply. Variation in NI for $A_{i} / A_{T}$ between 0.6 and 0.85 is less than $5 \%$ at any precipitation amount. When rainfed production is economically viable, the decision of what portion of the available land to irrigate with a limited water supply has little effect on NI. The producer who anticipates about $300 \mathrm{~mm}$ of precipitation can reduce the risk of greater or lesser amounts by increasing the irrigated area with minimal risk of NI loss.

\section{DEFICIT IRRIGATION MANAGEMENT WITH Limited PUMPING CAPACITY}

In several irrigated areas in western Kansas, eastern Colorado, and northern Texas and along the fringes of the High Plains aquifer, the aquifer has been partially depleted such that well yields have declined and the water supply rate is no longer adequate to fully irrigate the original irrigated area (Lamm et al., 2007; Schlegel et al., 2012). This condition is similar to that in the previous section in which the water supply is limited, and the NI analysis is the same. The primary difference is that, with constrained pumping capacity, the soil water deficit tends to increase through the season, and there is little flexibility to relieve plant water stress during critical growth stages. Therefore, the WPF is unlikely to be concave downward, and yield may even fall below a linear WPF. This condition would favor concentrating the available water on a smaller area to reduce the deficit during critical periods.

A dilemma faced by producers with an irrigation capacity constraint is how to manage soil water storage in the irrigated area. Producers can hedge by initiating irrigation early in the season, or even before planting, when their irrigation capacity exceeds crop water requirements as a means to fill the soil profile for later use (Schlegel et al., 2012). This may reduce the eventual deficit and increase yield but will also result in water loss from soil evaporation and, if early season precipitation exceeds expectation and is adequate to fill soil storage, deep percolation loss. Alternatively, producers with well capacity limitations can reduce peak crop water requirements by dividing the land between crops that mature early in the season, such as wheat or spring vegetables, and late season crops, such as dry edible beans or sunflower. Crops that are more tolerant of late season water deficits, such as sorghum, may have less potential NI at full irrigation but more stable harvest index and greater NI with late season stress (Stewart et al., 1975; Klocke et al., 2012). Another possible management practice is to divide the land between annual grain crops and biomass forages such as alfalfa (Fereres and Soriano, 2007). During critical stress periods of the grain crop, water can be concentrated on the grain crop. During early and late season periods of reduced water requirements, water can be applied to the forage crop to increase biomass production.

\section{Practices that May Improve YIELDS UNDER DEFICIT IRRIGATION}

Any practice that increases the portion of a water supply used by the crop for transpiration should increase the yields under DI. Tillage practices that reduce soil disturbance and maintain plant residues on the surface usually reduce evaporation loss and may improve infiltration and soil water storage and reduce surface runoff (Hergert et al., 1993; van Donk et al., 2010, Baumhardt et al., 2013). Improvements of the irrigation application system that increase irrigation uniformity and efficiency or reduce evaporation and losses also reduce the irrigation supply needed to achieve a target ET and yield (Evett, 2019). Irrigation system improvements that increase irrigation uniformity may provide less benefit with DI than with full irrigation because with DI even the areas that receive the most water may not exceed the soil water deficit. Variable-rate irrigation (VRI) systems (Evans et al., 2013) may improve NI with DI by tailoring the water application to the soil storage capacity and measured plant water stress and concentrating the limited water supply and other inputs on portions of the field that have greater yield potential (Evett et al., 2020, O’Shaughnessy et al., 2020). 
Water supply system improvements that increase flexibility of application timing allow irrigation to be strategically applied during critical growth stages and may increase the curvilinearity of the WPF and thus the yield with DI. Flexibility also allows adjustments for and increases the effectiveness of precipitation. Strategic crop water deficit management is critical to maximize yields with DI. Stress during non-critical periods may reduce biomass production without substantially reducing harvestable yield. Any strategy that improves the crop harvest index usually improves water productivity.

Plant transpiration per unit area can be reduced by reducing plant density (plants $\mathrm{m}^{-2}$ ). This is a common strategy to preserve stored soil water for critical growth stages in rainfed cropping in semi-arid regions. However, plant density reductions that are sufficient to reduce transpiration also reduce yield potential. Low density increases sunlight and air circulation at the soil surface, which may increase soil water evaporation. Therefore, with managed DI, it is doubtful that reduced plant density will increase water productivity unless the water supply is inadequate to initiate yield or provide sufficient water during critical growth stages. Because DI reduces yield, it is often possible to moderately reduce plant density and thus seed cost below that used with full irrigation without further impacting ET or yield (Schlegel et al., 2012).

Pest pressures may increase with DI. Small canopies and less canopy ground cover may result in greater weed pressure. Weeds compete with the crop for limited water. Waterstressed plants may be more susceptible to pest pressures such as spider mite infestations or the effects of root worm damage in maize. Minimizing pest and weed pressures is critical with DI.

Salts in irrigation water accumulate in the plant root zone as water is removed via ET. DI does not provide deep percolation to leach salts. When precipitation is not sufficient to leach salts, especially when the irrigation water contains substantial amounts of salts, soil salinity must be carefully monitored and managed. This may require periodic excess irrigation to leach salts.

Partial root zone drying has been tested as a method to signal water stress conditions to the plant so that it closes stomates and reduces transpiration (Chai et al., 2016). However, stomate closure also reduces $\mathrm{CO}_{2}$ assimilation and biomass production. Although the technique may help the crop survive drought conditions, it is not clear that practices that reduce transpiration improve water productivity with managed DI.

A large effort has been invested recently in developing drought-tolerant crops through both conventional breeding and genetic modification. It is unclear if these new varieties can increase water productivity under managed DI (Blum, 2009). Drought tolerance (surviving periods of large water deficits) is a different physiological response than improving water productivity under managed DI. Although plants have evolved to survive in semi-arid and arid climates, these plants usually specialize in survival rather than productivity.

\section{UNCERTAINTY UNDER DEFICIT IRRIGATION}

An important aspect of a DI decision is risk. Due to the curvilinear IWPF, DI increases yield uncertainty when the water supply varies from the anticipated amount. For example, for the IWPF in figure 2 , the yield is $50 \%$ more sensitive to variations in precipitation amount at an irrigation application of $200 \mathrm{~mm}$ compared to $400 \mathrm{~mm}$. Sensitivity to uncertainty in the WPF also increases with DI. Risk-averse growers may avoid or reduce DI to reduce yield and income risk (English, 1981). In addition to water supply risks, DI crops may be more sensitive to pest pressures and soil salinity.

English (1990) points out that because the range of DI water application over which the NI exceeds that with full irrigation is often wide, the risk of income loss compared to full irrigation may be small. Figures 3 to 6 illustrate conditions under which the NI is insensitive to irrigation amount for both an unlimited (but expensive) and a limited irrigation supply. Figure 6 shows that NI is relatively insensitive to the decision of how much land to irrigate with a limited water supply, even though yield and NI are sensitive to precipitation. However, those NI analyses assume that costs are adjusted appropriately for anticipated yield. After planting, most production costs are allocated, and risk is primarily dependent on yield loss.

Crops that provide the greatest NI under expected conditions may be sensitive to yield and income loss if the water supply does not meet expectations. Risk-averse producers may choose to grow crops that are less sensitive to unanticipated reductions in water supply, for example, crops with a flatter IWPF. Crop mixes can be selected that balance the risk (Hergert et al., 1993).

Production costs must be appropriate for the anticipated yields to achieve the full economic benefits of DI. This requires that the DI plan be determined before most crop inputs are applied. Error in yield prediction may result in either over-application of inputs or input-limited yields. DI also requires a dependable and flexible water supply and application system and good irrigation management, including precipitation forecasting and precision irrigation scheduling, to avoid excessive water deficits during critical periods.

Crop insurance is an important risk reduction tool for many U.S. growers of major commodity crops. Although the U.S. federal crop insurance agency is considering how to appropriately insure DI crops, crop insurance is currently difficult to acquire for DI crops (RMA, 2018). This discourages many growers from using DI.

Although DI increases yield uncertainty, it provides some potential benefits. To achieve maximum yield, portions of a field are often over-irrigated and precipitation is conservatively estimated. Both result in greater water runoff or deep percolation that may result in nutrient loss and downstream water quality degradation. DI reduces water loss and, unless the lost water is fully reused downstream, improves water resource use. 


\section{LOOKING TO THE FUTURE}

Current overuse of water resources and anticipated trends in human population growth, environmental restoration, and climate change will result in less water available for agricultural irrigation in the future. Irrigation water supply will be limited by shortages, regulation, and market competition. Managed DI to maximize agricultural production and farm incomes will become more common. Use of DI will induce growers to improve their irrigation systems and management practices and be more strategic about irrigation scheduling and water application. Water supply costs and constraints may require irrigated agriculture to grow greater-value crops to maintain profits.

Much remains to be learned about maximizing productivity with limited water supplies. Research around the world is improving our understanding of crop physiological responses to water stress, but more knowledge is needed. Determining water stress impacts on yield at different growth stages is especially critical. With this information, water application can be scheduled to minimize stress impacts and increase yields and WP under DI. Improving real-time information about crop and climatic conditions with sensors and data communication, analysis, and presentation technologies will enable irrigation managers to strategically apply their limited water to maximize productivity.

As DI becomes more common, productivity-limiting soil salinity will likely become more widespread, especially in semi-arid and arid regions. DI will require monitoring and management of soil salinity.

Advances in genetic analysis and modification will enable improvements in plants' ability to remain productive when transpiration is reduced. Identification of plant traits that improve water stress tolerance will be critical to genetic yield improvements. Plant responses to water stress are complex, and the basic physiological connection between transpiration and $\mathrm{CO}_{2}$ uptake in crop plants may limit major reductions in crop water requirements in the near future (Blum, 2009). Genetic and management improvements will likely continue to increase crop yields and thus water productivity even if water requirements are not reduced.

Atmospheric $\mathrm{CO}_{2}$ concentration is expected to continue to increase, which could potentially enable plants to absorb more $\mathrm{CO}_{2}$ per unit of transpiration. However, increased atmospheric $\mathrm{CO}_{2}$ also results in higher air temperatures, which increases the vapor pressure deficit and evaporative demand. Thus far, the net effect of climate change on crop water productivity is unknown.

\section{CONCLUSIONS}

Water shortages will result in greater use of deficit irrigation (DI). DI should be managed to maximize NI with acceptable risk. ET-based WPFs are required to estimate the DI amount that maximizes NI. These WPFs can be converted to IWPFs for specific climatic and management conditions. Expensive water, low irrigation efficiency, low rainfed yields, and flexible water supply increase the relative benefit of DI. For many situations, if production costs are adjusted for anticipated yield, NI is relatively insensitive to the irrigation amount. Thus, producers may adjust DI strategies for other management objectives, such as risk reduction, without substantial reduction in predicted NI.

\section{REFERENCES}

Barrett, J. W., \& Skogerboe, G. V. (1980). Crop production functions and the allocation and use of irrigation water. Agric. Water Mgmt., 3(1), 53-64. https://doi.org/10.1016/03783774(80)90015-3

Baumhardt, R. L., Schwartz, R., Howell, T., Evett, S. R., \& Colaizzi, P. (2013). Residue management effects on water use and yield of deficit-irrigated cotton. Agron. J., 105(4), 10261034. https://doi.org/10.2134/agronj2012.0361

Berck, P., \& Helfand, G. (1990). Reconciling the Von Liebig and differentiable crop production functions. American J. Agric. Econ., 72(4), 985-996. https://doi.org/10.2307/1242630

Blum, A. (2009). Effective use of water (EUW) and not water use efficiency (WUE) is the target of crop yield improvement under drought stress. Field Crops Res., 112(2), 119-123. https://doi.org/10.1016/j.fcr.2009.03.009

Briggs, L. J., \& Shantz, H. L. (1913). The water requirements of plants: I. Investigation in the Great Plains in 1910 and 1911. Bulletin 284. Washington, DC: USDA Bureau of Plant Industries.

Briggs, L. J., \& Shantz, H. L. (1914). Relative water requirements of plants. J. Agric. Res., 3, 1-63.

CDWR. (2020). SGMA groundwater management. Sacramento, CA: California Department of Water Resources. Retrieved from https://water.ca.gov/Programs/GroundwaterManagement/SGMA-Groundwater-Management

Chai, Q., Gan, Y., Zhao, C., Xu, H.-L., Waskom, R. M., Niu, Y., \& Siddique, K. H. (2015). Regulated deficit irrigation for crop production under drought stress. A review. Agron. Sustain. Dev., 36(1), article 3. https://doi.org/10.1007/s13593-015-0338-6

Comas, L. H., Trout, T. J., DeJonge, K. C., Zhang, H., \& Gleason, S. M. (2019). Water productivity under strategic growth stagebased deficit irrigation in maize. Agric. Water Mgmt., 212, 433440. https://doi.org/10.1016/j.agwat.2018.07.015

de Wit, C. T. (1958). Transpiration and crop yield. Verslagen van Landbouwkundige Onderzoekingen 64.6. Wageningen, The Netherlands: Institute of Biological and Chemical Research on Field Crops and Herbage.

Doorenbos, J., \& Kassam, A. H. (1979). Yield response to water. FAO Irrigation and Drainage Paper No. 33. Rome, Italy: United Nations FAO.

English, M. J. (1981). The uncertainty of crop models in irrigation optimization. Trans. ASAE, 24(4), 917-921. https://doi.org/10.13031/2013.34364

English, M. J. (1990). Deficit irrigation: I. Analytical framework. J. Irrig. Drain. Eng., 116(3), 399-412. https://doi.org/10.1061/(ASCE)0733-9437(1990)116:3(399

English, M. J., James, L., \& Chen C., F. (1990). Deficit irrigation: II. Observations in Columbia basin. J. Irrig. Drain. Eng., 116(3), 413-426. https://doi.org/10.1061/(ASCE)07339437(1990)116:3(413

Expósito, A. \& Berbel, J. (2020). Microeconomics of deficit irrigation and subjective water response function for intensive olive groves. Water, 8(6), article 254. https://doi.org/10.3390/w8060254

Evans, R. G., LaRue, J., Stone, K. C., \& King, B. A. (2013). Adoption of site-specific variable-rate sprinkler irrigation systems. Irrig. Sci., 31(4), 871-887. https://doi.org/10.1007/s00271-012-0365-x 
Evett, S. R., Marek, G. W., Colaizzi, P. D., Brauer, D. K., \& O'Shaughnessy, S. A. (2019). Corn and sorghum ET, E, yield, and CWP as affected by irrigation application method: SDI versus mid-elevation spray irrigation. Trans. ASABE, 62(5), 1377-1393. https://doi.org/10.13031/trans.13314

Evett, S. R., O’Shaughnessy, S. A., Andrade, M. A., Kustas, W. P., Anderson, M. C., Schomberg, H. S., \& Thompson, A. (2020). Precision agriculture and irrigation: Current U.S. perspectives. Trans. ASABE, 63(1), 57-67. https://doi.org/10.13031/trans.13355

Fereres, E., \& Soriano, M. A. (2007). Deficit irrigation for reducing agricultural water use. J. Exp. Bot., 58(2), 147-159. https://doi.org/10.1093/jxb/erl165

Fernández, J. E., Alcon, F., Diaz-Espejo, A., Hernandez-Santana, V., \& Cuevas, M. V. (2020). Water use indicators and economic analysis for on-farm irrigation decision: A case study of a super high density olive tree orchard. Agric. Water Mgmt., 23, article 106074. https://doi.org/10.1016/j.agwat.2020.106074

Grafton, R. Q., Williams, J., Perry, C. J., Molle, F., Ringler, C., Steduto, P., ... Allen, R. G. (2018). The paradox of irrigation efficiency. Science, 361(6404), 748-750. https://doi.org/10.1126/science.aat9314

Hanks R., J. (1983). Yield and water use relationships: An overview. In H. M. Taylor, W. R. Jordan, \& T. R. Sinclair (Eds.), Limitations to efficient water use in crop production (pp. 1-27). Madison, WI: ASA.

Hargreaves, G. H., \& Samani, Z. (1984). Economic considerations of deficit irrigation. J. Irrig. Drain Eng., 110(4), 343-358. https://doi.org/10.1061/(ASCE)0733-9437(1984)110:4(343

Hergert, G. W., Klocke, N. L., Petersen, J. L., Nordquist, P. T., Clark, R. T., \& Wicks, G. A. (1993). Cropping systems for stretching limited irrigation supplies. J. Prod. Agric., 6(4), 520529. https://doi.org/10.2134/jpa1993.0520

Hexem, R. W., \& Heady, E. O. (1978). Water production functions and irrigated agriculture. Ames, IA: Iowa State University Press.

Howell, T. A. (1990). Relationships between crop production and transpiration, evapotranspiration, and irrigation. In B. A. Stewart \& D. R. Nielsen (Eds.), Irrigation of agricultural crops. Agronomy Monograph No. 30. Madison, WI: ASA.

Howell, T. A. (2001). Enhancing water use efficiency in irrigated agriculture. Agron. J., 93, 281-289.

Kisekka, I., Aguilar, J. P., Rogers, D. H., Holman, J., O’Brien, D. M., \& Klocke, N. (2016). Assessing deficit irrigation strategies for corn using simulation. Trans. ASABE, 59(1), 303-317. https://doi.org/10.13031/trans.59.11206

Klocke, N. L., Currie, R. S., Tomsicek, D. J., \& Koehn, J. W. (2012). Sorghum yield response to deficit irrigation. Trans. ASABE, 55(3), 947-955. https://doi.org/10.13031/2013.41526

Klocke, N. L., Stone, L. R., Clark, G. A., Dumler, T. J., \& Briggeman, S. (2006). Water allocation model for limited irrigation. Appl. Eng. Agric., 22(3), 381-389.

https://doi.org/10.13031/2013.20458

Lamm, F. R., Stone, L. R., \& O’Brien, D. M. (2007). Crop production and economics in northwest Kansas as related to irrigation capacity. Appl. Eng. Agric., 23(6), 737-745. https://doi.org/10.13031/2013.24057

Martin, D. L., Gilley, J. R., \& Supalla, R. J. (1989a). Evaluation of irrigation planning decisions. J. Irrig. Drain Eng., 115(1), 58-77. https://doi.org/10.1061/(ASCE)0733-9437(1989)115:1(58

Martin, D. L., Supalla, R. J., Thompson, C. L., McMullen, B. P., Hergert, G. W., \& Burgener, P. A. (2010). Advances in deficit irrigation management. ASABE Paper No. IRR109277. St. Joseph, MI: ASABE. https://doi.org/10.13031/2013.35870
Martin, D., van Brocklin, J., \& Wilmes, G. (1989b). Operating rules for deficit irrigation management. Trans. ASAE, 32(4), 12071215. https://doi.org/10.13031/2013.31136

McGuire, V. L. (2017). Water-level and recoverable water in storage changes, High Plains aquifer, predevelopment to 2015 and 2013-15. USGS Scientific Investigations Report 2017-5040. Reston, VA: U.S. Geological Survey. https://doi.org/10.3133/sir20175040

Mead, E., \& Johnson, C. T. (1900). The use of water in irrigation: Report of investigations made in 1899. Bulletin 86. Washington, DC: USDA Office of Experiment Stations. Retrieved from https://babel.hathitrust.org/cgi/pt?id=wu.89037169455\&view=1 up\&seq $=11$

Mustek, J. T., \& Dusek, D. A. (1980). Irrigated corn yield response to water. Trans. ASAE, 23(1), 92-98. https://doi.org/10.13031/2013.34531

NARD. (2019). NRD groundwater quantity regulations across Nebraska, November 2019. Lincoln, NE: Nebraska Association of Resource Districts. Retrieved from https://www.nrdnet.org/sites/default/files/gwam_combined_map compressed.pdf

O’Shaughnessy, S. A., Kim, M., Andrade, M. A., Colaizzi, P. D., \& Evett, S. R. (2020). Site-specific irrigation of grain sorghum using plant and soil water sensing feedback: Texas High Plains. Agric. Water Mgmt., 240, 106273.

Perry, C., Steduto, P., Allen, R. G., \& Burt, C. M. (2009). Increasing productivity in irrigated agriculture: Agronomic constraints and hydrological realities. Agric. Water Mgmt., 96(11), 1517-1524. https://doi.org/10.1016/j.agwat.2009.05.005

RMA. (2018). Why limited irrigation. Washington, DC: USDA Risk Management Agency. Retrieved from https://legacy.rma.usda.gov/fields/ks_rso/2018/Why-LimitedIrrigation.pdf

Rudnick, D. R., Irmak, S., West, C., Chavez, J. L., Kisekka, I., Marek, T. H., ... Schlegel, A. (2019). Deficit irrigation management of maize in the High Plains aquifer region: A review. JAWRA, 55(1), 38-55. https://doi.org/10.1111/17521688.12723

Schlegel, A. J., Stone, L. R., Dumler, T. J., \& Lamm, F. R. (2012). Managing diminished irrigation capacity with preseason irrigation and plant density for corn production. Trans. ASABE, 55(2), 525-531. https://doi.org/10.13031/2013.41394

Steduto, P., Hsiao, T. C., \& Fereres, E. (2007). On the conservative behavior of biomass water productivity. Irrig. Sci., 25(3), 189207. https://doi.org/10.1007/s00271-007-0064-1

Stewart, J. I., \& Hagan, R. M. (1973). Functions to predict effects of crop water deficits. J. Irrig. Drain. Eng., 99(4), 421-439.

Stewart, J. I., Hagen R., M., Pruitt W., O., Hanks R., J., Riley J., P., Danielson R., E., ... Jackson E., B. (1977). Optimizing crop production through control of water and salinity levels in the soil. PRWG 151-1. Logan, UT: Utah State University, Utah Water Research Laboratory.

Stewart, J. I., Misra, R. D., Pruitt, W. O., \& Hagan, R. M. (1975). Irrigating corn and grain sorghum with a deficient water supply. Trans. ASAE, 18(2), 270-280. https://doi.org/10.13031/2013.36570

Taylor, H. M., Jordan, W. R., \& Sinclair, T. R. (1983). Limitations to efficient water use in crop production. Madison, WI: ASA.

Trout, T. J., \& DeJonge, K. C. (2017). Water productivity of maize in the U.S. High Plains. Irrig. Sci., 35(3), 251-266. https://doi.org/10.1007/s00271-017-0540-1

Trout, T. J., \& Manning, D. T. (2019). An economic and biophysical model of deficit irrigation. Agron. J., 111(6), 31823193. https://doi.org/10.2134/agronj2019.03.0209

van Donk, S. J., Martin, D. L., Irmak, S., Melvin, S. R., Petersen, J. L., \& Davison, D. R. (2010). Crop residue cover effects on 
evaporation, soil water content, and yield of deficit-irrigated corn in west-central Nebraska. Trans. ASABE, 53(6), 1787-1797. https://doi.org/10.13031/2013.35805

Varzi, M. M., \& Grigg, N. (2019). Overcoming obstacles to deficit irrigation: Colorado case study. J. Water Resour. Plan. Mgmt., 145(10), 05019014. https://doi.org/10.1061/(ASCE)WR.19435452.0001107

Zwart, S. J., \& Bastiaanssen, W. G. (2004). Review of measured crop water productivity values for irrigated wheat, rice, cotton, and maize. Agric. Water Mgmt., 69(2), 115-133. https://doi.org/10.1016/j.agwat.2004.04.007

\section{APPENDIX}

\section{IWPF QUADRATIC MODEL}

The IWPF can be modeled by a quadratic equation anchored at the end points and at one intermediate point. The upper end point is the relative yield $(Y m=1.0)$ at the full irrigation amount $(\mathrm{Im})$. The full irrigation amount is ETm minus the sum of the effective seasonal precipitation and soil water depletion, divided by the irrigation efficiency, with full irrigation. The lower end point is the relative yield with no irrigation (rainfed yield, $k_{0}$ ). The intermediate point, the relative irrigated yield $\left(Y_{r z}\right)$ at a relative irrigation amount $(z=I / I m)$, defines the degree of curvilinearity of the relationship. The relationship is usually concave downward, so $k_{2}<0$.

$$
f(I)=k_{0}+k_{1} I+k_{2} I^{2}
$$

where

$$
f(I)=\text { relative crop yield }(Y / Y m) \text { for irrigation amount } I
$$$$
\left.k_{0}=\text { relative crop yield at } I=0 \text { (rainfed yield } / Y m\right)
$$

$$
\begin{gathered}
k_{2}=\left(Y_{r z}-k_{0}-z\left(1-k_{0}\right)\right) /\left(z(z-1) \operatorname{Im}^{2}\right) \\
k_{1}=\left(1-k_{0}-k_{2} \operatorname{Im}^{2}\right) / \operatorname{Im}
\end{gathered}
$$

For the IWPF shown in figure $2, k_{0}=0.31, I m=520 \mathrm{~mm}$, and $Y=0.83$ at $z=0.5$. Thus, $k_{2}=-1.17 \mathrm{E}^{-6}$ and $k_{1}=0.00192$. The relative yield is converted to the actual yield $\left(\mathrm{kg} \mathrm{ha}^{-1}\right)$ by multiplying by the full irrigation yield $(\mathrm{Ym})$.

\section{Parameters USEd in SCenarios ANd Figures 2 to 5}

Table A1. Parameters used to calculate WPF and IWPF (fig. 2). The left column lists parameters that define the quadratic relationships. For a normalized WPF, $x_{o}$ is the $x$-intercept (threshold ET) of the WPF. For the three efficiencies, the first parameter is the efficiency at ET $m$, the second is the relative ET below which the efficiency is 1.0, and the third is the degree of curvilinearity. The right column lists the constant, linear, and quadratic coefficients, respectively, for the quadratic relationships derived from the parameters. The last three values are ET $m$, in-season precipitation $(R)$, and seasonal soil water depletion $(S)$. Terms are defined in detail by Trout and Manning (2019).

Normalized water production function

$$
\begin{array}{rlrl}
x_{o} & =0.35 & A & =0.54 \\
Y_{o} & =0 & B & =1.54 \\
C & =0 & C & =0
\end{array}
$$

Precipitation efficiency

$\begin{array}{rlrl}E r_{1} & =0.7 & D & =0.80 \\ x_{r} & =0.5 & F & =0.90 \\ G & =-1 & G & =-1\end{array}$

Soil water storage efficiency

$$
\begin{array}{rlrl}
E s_{1} & =0.4 & H & =0.60 \\
x_{s} & =0.5 & J & =1.80 \\
K & =-2 & K & =-2
\end{array}
$$

Irrigation efficiency

$\begin{array}{rlrl}E i_{1} & =0.75 & L & =1.00 \\ x_{i} & =0.5 & M & =0.25 \\ N & =-0.5 & N & =-0.5\end{array}$

$\mathrm{ET} m=630 \mathrm{~mm}$

$R=300 \mathrm{~mm}$

$S=75 \mathrm{~mm}$

Table A2. Values for parameters defined in equations 1 to 6 and used in NI calculations for figures 3, 4, and 5. Im and $Y_{r}$ are calculated from the parameters in table A1 at ET $m$ and $I=0$, respectively. Because $I$ is given in depth (ha-mm ha ${ }^{-1}$ ), and $c_{i}$ is given in $\mathrm{m}^{3} \mathrm{ha}^{-1}$, the irrigation amount must be multiplied by 10 .

\begin{tabular}{ccc}
\hline Parameter & Figure 3 & Figures 4 and 5 \\
\hline$Y_{p i}\left(\mathrm{~kg} \mathrm{ha}^{-1}\right)$ & 12,500 & 12,500 \\
$W(\mathrm{~mm})$ & - & 300 \\
$I m(\mathrm{~mm})$ & 520 & 520 \\
$P_{y i}\left(\$ \mathrm{~kg}^{-1}\right)$ & 0.20 & 0.20 \\
$c_{y i}\left(\$ \mathrm{~kg}^{-1}\right)$ & 0.05 & 0.05 \\
$c_{i}\left(\$ \mathrm{~m}^{-3}\right)$ & 0.15 & 0.04 \\
$c_{A i}\left(\$ \mathrm{ha}^{-1}\right)$ & 800 & 800 \\
$c_{y r}\left(\$ \mathrm{ha}^{-1}\right)$ & - & 0.05 \\
$c_{A r}(\$)$ & - & 400 \\
$Y_{r}\left(\$ \mathrm{~kg}^{-1}\right)$ & - & 4500 \\
$k_{0}$ & - & 4500 \\
$k_{1}$ & - & 22.7 \\
$k_{2}$ & - & -0.0138 \\
\hline
\end{tabular}

